\title{
Peranan Kepemimpinan dalam Menerapkan Prinsip-Prinsip Good Governance di Instansi Pemerintahan Daerah
}

\author{
Aloi Kamarasyid \\ IAIN Syaikh Abdurrahman Siddik Bangka Belitung, Indonesia \\ aloialkam@yahoo.co.id
}

\begin{abstract}
An attempt to embody a quality, government officials clean and authoritative; the government has set some rules that must be implemented by all the elements government officials who serves as the man of the country and the man of the community. The performance of government agencies in the spotlight from various parties, especially since the reform movement demanding structural change in various fields. In short, today is going on a change from a bad administration pattern at the formation of a good administration. An effort to reach the level of efficiency work organization there needs to be improving performance. There are some things owned by the administration in creating good, so as to be assessed as being successful, his leadership among other: intelligence maturity you, social relations motivation and encouragement, performed sikap-sikap, humanitarian relationship oriented, duty and authority honest and open, demokrastis, and administrative participate and responsible. As for the principles of good governance at least some of the things that must be upheld and performed, namely: accountability, transparency, openness certainty hukumlegalitas, insurance participation, partnership, decentralization professional and proportionate, effective and efficient, productivity and quality of work.
\end{abstract}

Keywords; good administration, good governance, leadership.

\begin{abstract}
Abstrak
Usaha untuk mewujudkan aparatur pemerintah yang berkualitas, bersih dan berwibawa; pemerintah telah menetapkan beberapa peraturan yang harus dilaksanakan oleh semua unsur aparatur pemerintah yang berperan sebagai abdi negara dan abdi masyarakat. Kinerja instansi pemerintah menjadi sorotan dari berbagai pihak, terutama sejak berkembangnya gerakan reformasi yang menuntut perubahan struktural di berbagai bidang. Singkatnya dewasa ini sedang terjadi perubahan dari pola kepemerintahan yang buruk kearah terwujudnya kepemerintahan yang baik. Upaya untuk mencapai tingkat efisiensi kerja organisasi diperlukan adanya peningkatan kinerja pegawai. Ada beberapa hal yang dimiliki oleh pemimpin dalam menciptakan kepemerintahan yang baik, sehingga dapat dikatakan berhasil kepemimpinannya, antara lain: Kecerdasan, Kedewasaan dan keluasan hubungan sosial, Motivasi dan dorongan berprestasi, Sikap-sikap hubungan kemanusiaan, Berorientasi tugas dan kewenangan, Jujur dan terbuka, Demokrastis dan administratif, berpartisipasi dan bertanggungjawab. Sedangkan untuk prinsip-prinsip good governance paling tidak ada beberapa hal yang harus ditegakkan dan dilakukan, yaitu: Akuntabilitas, Transparansi, Keterbukaan, Kepastian hukum-legalitas, Jaminan, Partisipasi (kemitraan), Desentralisasi, Profesional dan proporsional, Efektif dan efisien, Produktivitas dan kualitas kerja.
\end{abstract}

Kata Kunci; administrasi yang baik, good governance, kepemimpinan.

accepted: 05-07-2019; published: 30-12-2019

Citation: Aloi Kamarasyid, 'Peranan Kepemimpinan dalam Menerapkan Prinsip-Prinsip Good Governance di Instansi Pemerintahan Daerah', Mawa'izh: Jurnal Dakwah dan Pengembangan Sosial Kemanusiaan, vol. 10 , no. 2 (2019), pp. 326-353. 
Mawaizh

Jurnal Dakwah dan Pengembangan Sosial Kemanusiaan

Vol. 10, no. 2 (2019), pp. 326-353.

DOI: https://doi.org/10.32923/maw.v10i2.738
ISSN (printed):2252-3022

ISSN (Online): 2614-5820 


\section{A. Pendahuluan}

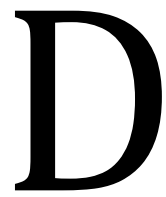
aerah memiliki kedudukan dan peran penting sejak diterapkannya otonomi daerah di Indonesia pada era reformasi. Praktik sentralisasi dan dominasi oleh pemerintah pusat kini telah berganti menjadi desentralisasi dan dekonsentrasi. Seiring dengan perkembangan pembangunan nasional di Indonesia saat ini telah membawa masyarakat kearah sikap, perilaku dan pola pikir yang lebih kritis, sehingga berdampak terhadap berbagai tuntutan pelayanan yang lebih baik dari waktu ke waktu. Konsekuensi dari kemajuan pola pikir masyarakat tersebut hendaknya menjadi motivasi bagi aparat pemerintah untuk mampu melaksanakan tugasnya secara maksimal dalam rangka memberikan pelayanan yang optimal terhadap berbagai tuntutan kebutuhan masyarakat, baik pelayanan civil maupun pelayanan public.

Pelaksanaan tugas secara maksimal dalam rangka memberikan pelayanan yang optimal terhadap berbagai tuntutan kebutuhan masyarakat, baik pelayanan civil maupun pelayanan public, seharusnya pemberdayaan aparat pemerintah lebih diarahkan pada peningkatan kualitas, produktivitas, efektivitas dan efesiensi seluruh tatanan administrasi pemerintah, termasuk peningkatan kemampuan, pengabdian, dedikasi serta loyalitas tinggi terhadap tugas yang menjadi tanggung jawabnya. Untuk itu secara keseluruhan diharapkan mampu melaksanakan tugas-tugas administrasi pemerintahan dengan sebaik-baiknya.

Berbagai upaya dalam rangka mewujudkan aparatur pemerintah yang berkualitas, bersih dan berwibawa (clean and good government), pemerintah telah menetapkan beberapa peraturan kepegawaian yang harus dilaksanakan oleh semua unsur aparatur pemerintah yang berperan sebagai abdi negara dan abdi masyarakat. Hal ini ditegaskan dalam Undang-Undang Nomor 43 Tahun 1999 Tentang Pokok-pokok Kepegawaian, yang menyatakan bahwa:

Dalam rangka mencapai tujuan nasional untuk mewujudkan masyarakat madani yang taat hukum, berperadaban modern, demokratis, makmur, adil, dan bermoral tinggi, diperlukan Pegawai Negeri yang merupakan unsur aparatur negara yang bertugas sebagai abdi masyarakat yang menyelenggarakan pelayanan secara adil dan merata, menjaga persatuan dan kesatuan bangsa dengan penuh kesetiaan kepada Pancasila dan Undang-Undang Dasar 1945. ${ }^{1}$

\footnotetext{
${ }^{1}$ Undang-Undang Nomor 43 Tahun 1999 Tentang Pokok-Pokok Kepegawaian.
} 
Sesuai dengan semangat otonomi daerah, sebagaimana diamanatkan oleh Undang-Undang Nomor 32 Tahun 2004 yang telah dirubah dengan Undang-Undang Nomor 9 Tahun 2015 dikatakan bahwa

Efektivitas dan efesiensi penyelenggaraan pemerintahan daerah perlu untuk ditingkatkan dengan lebih memperhatikan aspek-aspek hubungan antar susunan pemerintahan dan antar pemerintahan daerah, potensi dan keanekaragaman daerah, peluang dan tantangan persaingan global dengan memberikan kewenangan yang seluas-luasnya kepada daerah disertai dengan pemberian hak dan kewajiban penyelenggaraan otonomi daerah. Untuk melaksanakan berbagai tugas dalam rangka pelaksanaan otonomi daerah tersebut faktor aparat atau sumber daya manusia merupakan syarat yang perlu mendapat perhatian. ${ }^{2}$

Suatu organisasi baik itu formal maupun nonformal dibutuhkan seorang pemimpin yang dapat memberikan semangat kepada bawahannya, karena keberadaannya sangat penting untuk menjadi panutan bagi para bawahannya. Dengan adanya kepemimpinan akan membedakan karakteristik suatu organisasi dengan organisasi lainnya. Setiap pemimpin harus memahami dan mengatahui bakat dan posisi yang dimiliki oleh bawahannya ataupun yang dimiliki oleh dirinya sendiri. Dalam organisasi dibutuhkan peran yang mutlak dari seorang pemimpin dan para pegawainya yang masing-masing mempunyai tugas untuk mendukung kegiatan mencapai tujuan organisasi yang telah ditetapkan terlebih dahulu secara bersama-sama.

Seorang pemimpin yang baik itu pada dasarkan merupakan orang yang mampu membangkitkan semangat kerja dan menanamkan rasa percaya diri serta tanggung jawab pada bawahannya dalam melaksanakan tugas-tugasnya. Untuk itu seorang pemimpin dituntut bisa fleksibel dalam menggunakan kepemimpinannya yang berorientasi pada tugas dan hubungan antar manusia yang bertujuan untuk meningkatkan kematangan bawahannya.

Semangat kerja pegawai akan muncul dengan adanya kepemimpinan yang diterapkan seorang pemimpin dalam suatu organisasi untuk mencapai tujuan yang maksimal, sehingga pemimpin mampu menggerakkan orang lain yang menjadi bawahannya. Untuk itulah seorang pemimpin dituntut harus mampu menciptakan suasana dinamis serta mampu meningkatkan semangat kerja bawahannya.

2Undang-Undang Nomor 9 Tahun 2015 Tentang Pemerintahan Daerah. 
Seorang pemimpin haruslah mempunyai kemampuan memimpin yang baik agar tujuan organisasi dapat mudah tercapai. Karena itu, seorang pemimpin harus mampu untuk memotivasi, mempengaruhi, mengarahkan dan berkomunikasi dengan bawahannya. Di samping itu pemimpin hendaknya mempunyai perilaku atau kepemimpinan yang telah disesuaikan dengan situasi dan kondisi organisasi yang ia pimpin. Seorang pemimpin dapat bersifat fleksibel sehingga dapat menyesuaikan dirinya dengan tujuan organisasi yang hendak dicapai. Kefleksibelan ini sangat diperlukan sebab hal ini dapat menumbuhkan dan memacu semangat kerja para bawahannya.

Sekarang ini kinerja instansi pemerintah menjadi sorotan dari berbagai pihak, terutama sejak berkembangnya gerakan reformasi yang menuntut perubahan struktural di berbagai bidang. Perubahan yang paling mendasar adalah untuk mewujudkan karakter pemerintahan yang demokratis, transparan, akuntabel, bersih dan bebas korupsi, berorientasi kepada pasar dan peran serta aktif masyarakat dalam berbagai bidang. Singkatnya dewasa ini sedang terjadi perubahan dari pola kepemerintahan yang buruk (bad governance) kearah terwujudnya kepemerintahan yang baik (good governance).

Setiap permasalahan harus diatasi agar organisasi dapat mencapai tingkat efektivitas dan efisiensi terlebih lagi bagi organisasi pemerintahan yang mengemban beban sebagai birokrasi dalam melayani masyarakat yang terus maju dan berkembang. Salah satu upaya untuk mencapai tingkat efisiensi kerja organisasi diperlukan adanya peningkatan kinerja pegawai. Tujuannya adalah dalam konteks meningkatkan kualitas, efektivitas dan efesiensi kinerja pegawai termasuk kemampuan, disiplin, pengabdian, keteladanan dan kesejahteraan aparatnya serta untuk meningkatkan kemampuan dalam melayani, mengayomi serta menumbuhkan prakarsa dan peran aktif masyarakat dalam pembangunan dan tanggap terhadap kepentingan aspirasi masyarakat. Dengan kepemimpinan yang baik, maka akan dapat menerapkan prinsip-prinsip good governance suatu organisasi atau instansi tertentu, seperti di kantor gubernur,bupati/ walikota, camat, lurah,bahkan sampai kantor desa.

Memang banyak faktor yang harus diperhatikan untuk mewujudkan suatu organisasi agar bisa berjalan efektif dan efisien, antara lain: faktor resources (pola pikir/ 
akal) sumber daya manusia yang merupakan salah satu faktor penunjang dalam pencapaian tujuan dan keberhasilan organisasi atau instansi tersebut di samping faktor struktur, teknologi, motivasi dan kepemimpinan.

Semangat reformasi telah mewarnai pendayagunaan aparatur negara dengan tuntutan untuk mewujudkan administrasi negara yang mampu mendukung kelancaran dan keterpaduan pelaksanaan tugas dan fungsi penyelenggaraan pemerintahan negara dan pembangunan, menuntut pelaksanaan good governance ini berlaku pada setiap pemerintahan daerah yang sangat diperlukan dalam penyelenggaran otonomi daerah.

Good Governance yakni penyelenggaraan pemerintahan negara yang baik atau kepemerintahan yang baik. Penyelenggaraan kepemerintahan yang baik adalah pemerintah yang dekat dengan masyarakat dan dalam memberikan pelayanan harus sesuai dengan kebutuhan masyarakat. Sedangkan pemerintahan yang bersih adalah pemerintahan yang bebas dari korupsi, kolusi, dan nepotisme (KKN). Pemerintah sendiri telah ada kebijakan publik yang dijadikan instrument untuk menuju pemerintahan yang amanah. Oleh karena itu pemerintah di daerah dituntut untuk menerapkan prinsip-prinsip good governance. Salah satunya dalam menjalankan aktivitas pemerintahannya dituntut untuk selalu transparan dan diperlukan pertanggungjawaban yang tepat, jelas, nyata dihadapan publik.

Biasanya organisasi publik yang ada di setiap pemerintah daerah memerlukan sumber daya manusia yakni aparatur pemerintah daerah yang mampu mewujudkan karakteristik good governance. Pelaksanaan otonomi daerah ini bertujuan untuk mewujudkan percepatan pembangunan disetiap daerah disemua bidang.

Pelimpahan wewenang dari pemerintah pusat ke daerah adalah salah satu karakteristik yang merupakan sistem desentralisasi daerah yang menjadi impian masyarakat seluruh Indonesia. Percepatan otonomi daerah ini diharapkan mampu mengatasi semua permasalahan yang ada di daerah, termasuk pembangunan perekonomian, kesehatan, pendidikan, politik, hak asasi manusia, keadilan, hukum dan sebagainya termasuk juga pembangunan struktural organisasi. Dengan tujuan, baik sistem pembangunan maupun pelayanan publik bisa dilaksanakan dengan baik serta mengikutsertakan masyarakat setempat. 
Berdasarkan Undang-Undang Nomor 9 Tahun 2015 maka pemerintah daerah perlu dibantu oleh perangkatnya. Dalam gubernur, bupati/ wali kota sesuai dengan wewenangnya melimpah sebagian urusan otonomi daerrah dan tugas umum pemerintah kepada camat dan lurah sebagai perangkat daerah yang memimpin wilayah kelurahan. ${ }^{3}$

Misalnya, ditingkat kecamatan adalah wilayah kerja camat sebagai perangkat daerah dalam suatu kabupaten. Keberhasilan dalam melakukan pembangunan kecamatan itu sangat tergantung dari partisipasi masyarakat setempat, sektor swasta, lurah dalam perencanaan pembangunan di kecamatan tersebut. Seorang camat harus mampu berkerja sama dengan semua masyarakat dan mampu menampung masukanmasukan berupa sumbangan pemikiran, keluhan, kritikan serta saran. Masyarakat juga harus mampu mengelola sumber daya atau potensi apapun yang ada dalam lingkungannya untuk dapat mewujudkan kesejahteraannya. Oleh karena itu, semua permasalahan tidak terlepas dari dukungan seorang camat yang harus oleh lurah-lurah yang ada di wilayah serta arahan, bimbingan, dorongan dari bupati.

Kantor kecamatan merupakan tempat camat bekerja dibantu oleh para pegawainya dalam melayani kepentingan masyarakat harus menjadi birokrasi efektif dan efisien yang tercermin dalam pelayanan publik. Hal ini sesuai dengan visi dan misi kantor kecamatan tersebut. Misalnya, Visi: Terwujudnya kecamatan sebagai instansi pemerintah yang bermartabat dalam pelayanan masyarakat sesuai dengan prinsip melayani, profesionalisme, transparansi, dan informatif. Sedangkan, Misi: 1) Mewujudkan aparatur kecamatan yang profesional berdasarkan iptek dan imtaq. 2) Mewujudkan pelayanan publik.

Karena pelayanan publik yang baik akan memperlancar jalannya proses pembangunan atau kepentingan masyarakat disemua sektor dan subsektor, jangan sampai terhambat semuanya. Dapat dikatakan efektif tidak kepemimpinan camat dan kinerja pegawainya jika berorientasi pada kepuasan masyarakat. Agar dapat mewujudkan kepuasan masyarakat, maka pemimpinan dan para pegawainya tidak boleh mengabaikan prinsip-prinsip good governance untuk diterapkan.

33lbid, Undang-Undang Nomor 9 Tahun 2015. 
Berdasarkan pengamatan atau observasi dilapangan yang dilakukan peneliti di berbagai kantor kecamatan, ternyata masih belum optimalnya prinsip-prinsip good governance diterapkan, seperti belum transparansinya masalah waktu pelayanan, biaya, penegakan disiplin kerja pegawai, pemberian punishment maupun reward bagi pegawai, lemahnya kesadaran hukum dari pegawai dalam menerapkan keadilan terhadap pelayanan, kurang tanggapnya terhadap keluhan masyarakat.

\section{B. Pengertian Pemimpin dan Kepemimpinan}

Kepemimpinan dibutuhkan manusia, karena adanya suatu keterbatasan dan kelebihan-kelebihan tertentu pada manusia. Di satu pihak manusia memiliki kemampuan terbatas untuk memimpin, di pihak lain ada orang yang mempunyai kelebihan kemampuan untuk memimpin. Disinilah timbulnya kebutuhan akan pemimpin dan kepemimpinan.

Kepemimpinan merupakan kemampuan seseorang secara luas meliputi proses mempengaruhi dalam menentukan tujuan organisasi, memotivasi prilaku pengikut untuk mencapai tujuan, mempengaruhi untuk memperbaiki kelompok dan budayanya. Selain itu juga mempengaruhi interprestasi mengenai peristiwa-peristiwa para pengikutnya, pengorganisasian dan aktivitas-aktivitas untuk mencapai sasaran, memelihara hubungan kerjasama dan kerja kelompok dan memperoleh dukungan dan kerjasama dari orang-orang di luar kelompok atau organisasi.

Sedangkan pemimpin adalah orang yang diakui dan diterima orang lain atau kelompok atau dalam suatu organisasi baik itu organisasi formal maupun organisasi informal. Pemimpin merupakan figure yang mempunyai peranan penting dalam organisasi yang mampu menggerakan, mengarahkan dan memotivasi seluruh komponen yang terlibat dalam berbagai kegiatan dalam pencapaian tujuan organisasi. Dalam kenyataannya apapun bentuk suatu organisasi, pasti memerlukan seseorang untuk menempati posisi sebagai pimpinan (leader). Dengan adanya jabatan seseorang yang menduduki posisi pemimpin dalam organisasi, maka ia telah mengemban tugas melaksanakan kepemimpinan

Menurut Ati Cahyani pemimpin dapat didefinisikan sebagai "individu dalam kelompok atau organisasi yang bertugas membimbing dan mengkoordinir aktivitas 
kelompok atau organisasi tersebut". ${ }^{4}$ Menurut Kartini Kartono pemimpin adalah "seorang pribadi yang memiliki superioritas tertentu, sehingga dia memiliki kewibawaan dan kekuasaan untuk menggerakkan orang lain melakukan usaha bersama guna mencapai sasaran tertentu". 5

Pemimpin adalah pemandu, sekaligus panutan bagi yang dipimpin. Dari berbagai literatur yang ada, dapat dicatat bahwa pemimpin yang merupakan sosok yang menjadi panutan, dan penggerakan orang lain untuk sadar dan suka rela berpartisipasi di dalam suatu tujuan. Sedangkan kepemimpinan merupakan kemampuan yang harus dimiliki seseorang guna mempengaruhi, memotivasi, mengaktiviasi aneka potensi dan sumber daya yang ada sehingga organisasi yang dipimpinnya mampu berjalan secara efektif dalam rangka mengupayakan perwujudan cita-cita. ${ }^{6}$

Menurut Sondang P. Siagian pemimpin adalah: Seorang pribadi yang memiliki kecakapan dan kelebihan khususnya kecakapan kelebihan di satu bidang sehingga dia mempengaruhi orang lain untuk bersama-sama melakukan aktivitas-aktivitas tertentu demi pencapaian satu atau beberapa tujuan. Jadi pemimpin itu merupakan seorang yang memiliki satu atau beberapa kelebihan sebagai predisposisi (bakat yang dibawa sejak lahir) dan merupakan kebutuhan dari satu situasi, sehingga dia mempunyai kekuasaan dan kewibawaan untuk mengarahkan dan membimbing bawahan. Dia juga mendapatkan pengakuan serta dukungan dari bawahannya dan mampu menggerakkan bawahan ke arah tujuan tertentu. ${ }^{7}$

Menurut James A. Lee, bahwa pemimpin itu harus memiliki beberapa kelebihan, yaitu: 1) Kapasitas: kecerdasan, kewaspadaan, kemampuan berbicara atau verbal facility, keaslian, kemampuan menilai. 2) Prestasi atau achievement: gelar kesarjanaan, ilmu pengetahuan, perolehan dalam olahraga dan lain sebagainya. 3) Tanggung jawab: mandiri, berinisiatif, tekun, ulet, percaya diri, agresif dan punya hasrat untuk unggul. 4) Partisipasi: aktif, memiliki sosiabilitas tinggi, mampu bergaul, kooperatif atau suka bekerja sama, mudah menyesuaikan diri, punya rasa humor. 6) Status: meliput kedudukan sosial ekonomi yang cukup tinggi, popular, tenar. ${ }^{8}$

\footnotetext{
${ }^{4}$ Ati Cahyani, Dasar-Dasar Organisasi dan Manajemen, (Jakarta: Grasindo, 2003), p. 72.

5 Harbani Pasolong, Teori Administrasi Publik, (Bandung: CV. Alfabeta, 2010), p. 109.

${ }^{6}$ A.W. Widjaja, Pola Kepemimpinan dan Kepemimpinan Pancasila, (Bandung: Armico, 2003), p. 87.

${ }^{7}$ Hadari Nawawi, Kepemimpinan Mengefektifkan Organisasi, (Yogyakarta: BPFE, 2006), p. 28.

${ }^{8}$ Kartini Kartono, Pemimpin dan Kepemimpinan, (Jakarta. Raja Grafindo Persada, 2006), p.36.
} 
Selanjutnya George R.Terry menuliskan sepuluh sifat pemimpin yang unggul yaitu :

1. Kekuasaan

Syarat pokok bagi pemimpin yang harus bekerja lama dan berat pada waktu yang lama serta tidak teratur dan di tengah-tengah situasi yang sering tidak menentu.

2. Stabilitas emosi

Pemimpin yang baik memiliki emosi yang stabil artinya tidak mudah marah, tersinggung perasaan dan tidak meledak-ledak secara emosional. Ia menghormati martabat orang lain, toleran terhadap kelemahan orang lain dan bisa memaafkan kesalahan-kesalahan yang tidak terlalu prinsipil.

3. Pengetahuan tentang relasi insane

Salah satu tugas pokok pemimpin adalah memajukan dan mengembangkan semua bakat serta potensi anak buah untuk bias bersama-sama maju dan mengecap kesejahteraan. Karena itu pemimpin diharapkan memiliki pengetahuan tentang sifat, watak dan perilaku anggota kelompoknya, agar ia bisa menilai kelebihan dan kelemahan/keterbatasan pengikutnya yang disesuaikan dengan tugas-tugas atau pekerjaan yang akan diberikan pada masing-masing individu.

4. Kejujuran

Pemimpin yang baik itu harus memiliki kejujuran yang tinggi yaitu jujur pada diri sendiri dan pada orang lain (terutama bawahannya). Dia selalu menepati janji, tidak munafik, dapat dipercaya dan berlaku adil terhadap semua orang.

5. Objektif

Pertimbangan pemimpin harus berdasarkan hati nurani yang bersih supaya objektif (tidak subjektif, berdasarkan prasangka sendiri). Dia akan mencari bukti-bukti nyata dan sebab musabab setiap kejadian dan memberikan alasan yang rasional atas penolakannya.

6. Dorongan pribadi

Keinginan dan kesediaan untuk menjadi pemimpin itu harus muncul dari dalam hati sanubari sendiri. Dukungan dari luar akan memperkuat hasrat sendiri untuk memberikan pelayanan dan pengabdian diri kepada kepentingan orang banyak.

7. Ketrampilan berkomunikasi 
Pemimpin diharapkan mahir menulis dan berbicara, mudah menangkap maksud orang lain, cepat menangkap esensi pernyataan orang luar dan mudah memahami maksud para anggotanya. Juga pandai mengkoordinasikan macam-macam sumber tenaga manusi dan mahir mengintegrasikan pelbagai opini serta aliran yang berbeda-beda untuk mencapai kerukunan dan keseimbangan.

8. Kemampuan mengajar

Pemimpin yang baik diharapkan dapat menjadi guru yang baik bagi pengikutnya, mau memberikan loyalitas dan partisipasinya.

9. Ketrampilan Sosial

Pemimpin juga diharapkan memiliki kemampuan untuk "mengelola" manusia, agar mereka dapat mengembangkan bakat dan potensinya. Pemimpin dapat mengenali segi-segi kelemahan dan kekuatan setiap anggotanya, agar bisa ditempatkan pada tugas-tugas yang cocok dengan pembawaan masing-masing.

10. Kecakapan teknis atau kecakapan manajerial

Pemimpin harus superior dalam satu atau beberapa kemahiran teknis tertentu. Juga memiliki kemahiran manajerial untuk membuat rencana, mengelola, menganalisis keadaan, membuat keputusan, mengarahkan, mengontrol dan memperbaiki situasi tidak mapan. Tujuannya adalah agar tercapainya efektivitas kerja, keuntungan maksimal dan kebahagiaan serta kesejahteraan anggota sebanyak-banyaknya. 9

Lebih lanjut, Stone dan Sachs mengemukakan, ada empat hal yang strategis bagi pimpinan dalam memimpin organisasi, yaitu: a) Memberdayakan anggota organisasi. Menciptakan lingkungan pelatihan, b) Mengupayakan agar visi, misi, dan menjadi nilainilai organisasi menjadi milik anggota organisasi, c) Membuka diri terhadap perkembangan dan mudah menyesuaikan diri terhadap perkembangan. ${ }^{10}$

Menurut Sondang P. Siagian mengatakan bahwa tipe kepemimpinan yang tepat bagi seorang pemimpin adalah tipe yang demokratik dengan karakteristik :a) Kemampuan pemimpin mengintegrasikan organisasi pada peranan dan porsi yang tepat, b) Mempunyai persepsi yang holistic, c) Menggunakan pendekatan yang integralistik, d) Organisasi secara keseluruhan, e) Menjunjung tinggi harkat dan

${ }^{9}$ Ibid.,p. 3.

10 J. Kaloh, Kepemimpinan Kepala Daerah: Pola Kegiatan, Kekuasaan, dan Perilaku Kepala Daerah Dalam Pelaksanaan Otonomi Daerah, (Jakarta: Sinar Grafika, 2009), p. 11. 
martabat bawahan, f) Bawahan berpartisipasi dalam pengambilan keputusan, g) Terbuka terhadap ide, pandangan dan saran dari bawahannya, h) Teladan, i) Bersifat rasional dan obyektif, j) Memelihara kondisi kerja yang kondusif, inovatif dan kreatif.11

Sedangkan definisi kepemimpinan menurut Sondang P. Siagian adalah "kemampuan seseorang untuk mempengaruhi orang lain (dalam hal ini para bawahannya) sedemikian rupa sehingga orang lain itu mau melakukan kehendak pemimpin meskipun secara pribadi hal itu mungkin tidak disenanginya". Jika definisi itu disimak dengan cermat akan terlihat paling sedikit ada tiga hal, yaitu: a) Dari seseorang yang menduduki jabatan pemimpin dituntut kemampuan tertentu yang tidak dimiliki oleh sumber daya manusia lainnya dalam organisasi. b) Kepengikutan sebagai elemen penting dalam menjalankan kepemimpinan. c) Kemampuan mengubah 'egosentrisme' para bawahan menjadi 'organisasi-sentrisme'.12

Menurut Goetsch dan Davis, kepemimpinan merupakan kemampuan untuk membangkitkan semangat orang lain agar bersedia dan memiliki tanggungjawab total terhadap usaha mencapai atau melampaui tujuan organisasi. Kepemimpinan merupakan kemampuan seseorang dalam membangkitkan motivasi atau semangat orang lain dengan jalan memberikan inspirasi atau mengilhami. ${ }^{13}$

Pengertian kepemimpinan menurut Matondang adalah suatu proses dalam mempengaruhi orang lain agar mau atau tidak melakukan sesuatu yang diinginkan. Ada juga yang menyatakan bahwa kepemimpinan (leadership) adalah hubungan interaksi antara pengikut (follower) dan pemimpin dalam mencapai tujuan bersama. ${ }^{14}$

Menurut Yulk ada beberapa definisi yang dianggap mewakili kepemimpinan adalah sebagai berikut: a) Kepemimpinan adalah perilaku dari seorang individu yang memimpin aktivitas-aktivitas suatu kelompok ke suatu tujuan yang ingin dicapai bersama (share goal); b) Kepemimpinan adalah pengaruh antar pribadi yang dijalankan dalam situasi tertentu, serta diarahkan melalui proses komunikasi kearah pencapaian tujuan; c) Kepemimpinan adalah pembentukan awal serta pemeliharaan struktur dalam

\footnotetext{
${ }^{11}$ Hadari Nawawi, Kepemimpinan Mengefektifkan Organisasi, p. 136.

${ }^{12}$ Sondang P.Siagian, Kiat Meningkatkan Produktivitas Kerja, (Jakarta: PT. Renika Cipta, 2002), p.
} $62-63$.

13M.N Nasution,Manajemen Mutu Terpadu, (Jakarta: Ghalia Indonesia, 2001), p.149.

${ }^{14}$ Matondang, Kepemimpinan Budaya Organisasi dan Manajemen Stratejik. (Yogyakarta: Graha Ilmu, 2008), p. 5. 
harapan dan interaksi; d) Kepemimpinan adalah peningkatan pengaruh sedikit demi sedikit, pada dan berada di atas kepatuhan mekanis terhadap pengarahan-pengarahan rutin organisasi; e) Kepemimpinan adalah proses mempengaruhi aktivitas-aktivitas sebuah kelompok yang diorganisasi ke arah pencapaian tujuan; f) Kepemimpinan adalah sebuah proses pemberian arti (pengarahan yang berarti) terhadap asaha kolektif, dan yang mengakibatkan kesediaan untuk melakukan usaha yang diinginkan untuk mencapai sasaran; g) Para pemimpin adalah mereka yang secara konsisten memberikan kontribusi yang efektif terhadap orde sosial, serta yang diharapakan dan dipersepsikan melakukannya. ${ }^{15}$

Ralph M. Stogdill menghimpun sebelas kelompok dari keseluruhan definisi tentang kepemimpinan, yaitu sebagai berikut: a) Kepemimpinan sebagai pusat proses kelompok; b) Kepemimpinan sebagai kepribadian yag berakibat; c) Kepemimpinan sebagai seni menciptakan kesepakatan; d) Kepemimpinan sebagai kemampuan mempengaruhi; e) Kepemimpinan sebagai tindakan prilaku; f) Kepemimpinan sebagai suatu bentuk bujukan; g) Kepemimpinan sebagai suatu hubungan kekuasaan; h) Kepemimpinan sebagai sarana pencapaian tujuan; i) Kepemimpinan sebagai hasil interaksi; j) Kepemimpinan sebagai pemisahan peranan; k) Kepemimpinan sebagai awal struktur. ${ }^{16}$

Berdasarkan pendapat George R. Terry, konsep kepemimpinan terdapat tiga hal pokok, yaitu: a) Dalam menduduki jabatannya seorang pemimpin harus mempunyai kemampuan dalam mempengaruhi atau mengajak bawahannya untuk bekerja sama; b) Kegiatan mempengaruhi itu harus menghasilkan kerja sama secara suka rela antara para organisasi, bukan merupakan kegiatan individual; c) Kerjasama yang dilakukan untuk mencapai suatu tujuan yang diinginkan oleh pemimpin dalam organisasi tersebut. ${ }^{17}$

Berdasarkan dari beberapa pengertian di atas, dapat ditarik kesimpulan: pemimpin menduduki posisi yang sangat penting dan utama karena merupakan pihak yang menentukan berbagai aspek dalam kehidupan organisasinya, seperti menetapkan

\footnotetext{
${ }^{15}$ Husaini Usman, Manajamen, (Jakarta: Bumi Akshara, 2009), p. 279.

16 Inu Kencana Syafi ie, Kepemimpinan Kepemerintahan Indonesia, (Bandung: PT. Refika Aditama, 2003), p. 3

${ }^{17}$ Hadari Nawawi, Kepemimpinan Mengefektifkan Organisasi, p. 23.
} 
tujuan, pembagian dan pembidangan kerja, struktur, cara kerja dan lain sebagainya. Peranan-peranan tersebut dapat dilaksanakan seorang pemimpin dengan atau tanpa mempartisipasi anggotanya, namun yang terpenting adalah kemampuannya menetapkan keputusan mengenai berbagai aspek kehidupan organisasi tersebut. Dengan keputusan-keputusan itu pemimpin harus mampu menggerakkan dan mempengaruhi anggotanya agar melaksanakan tugas pokok masing-masing secara efektif dan efisien. Di sisi lain adanya persamaan persepsi tentang kemampuan pemimpin dalam mempengaruhi dan memberikan arahan kepada bawahannya untuk melakukan kegiatan/aktivitas organisasi secara terintegrasi.

\section{Konsep Kepemimpinan}

Sebenarnya dalam merumuskan sebuah definisi yang tepat mengenai konsep kepemimpinan atau leadership adalah merupakan sebuah upaya yang sulit karena akan timbul sudut pandang yang berbeda antara setiap ahli dalam membuat batasan yang dikehendakinya. Kita akan menemukan sejumlah definisi yang sama banyaknya dengan orang atau para ahli yang memberikan batasan tentang kepemimpinan tersebut.

Menurut Keith Davis, merumuskan empat sifat umum yang mempengaruhi pengaruh terhadap keberhasilan kepemimpinan organisasi, yaitu:

1. Kecerdasan

Seorang pemimpin mempunyai tingkat kecerdasan yang lebih tinggi dibandingkan dengan yang dipimpin. Maksudnya adalah seorang pemimpin jika mempunyai intelegensi yang rendah (cenderung bodoh), jika menjadi pemimpin akan banyak mengalami hambatan untuk mewujudkan kepemimpinan yang efektif. Namun sebaliknya seorang pemimpin yang mempunyai tingkat intelegensi/kecerdasan yang relatif tinggi harus mempunyai kemampuan berfikir efektif dan memerlukan juga kemampuan menyaring informasi/data yang masuk, baik berupa umpan balik (feed back) hasil pengamatan, maupun yang bersumber dari orang lain.

2. Kedewasaan dan keluasan hubungan sosial

Seorang pemimpincenderung matang dan mempunyai emosi yang stabil, serta mempunyai perhatian yang luas terhadap aktivitas-aktivitas sosial.Seorang pemimpin harus mampu mengendalikan kepribadiannya dengan baik dalam 
mempengaruhi, mengarahkan, mengkomunikasikan serta melakukaninteraksi sosial dengan orang-orang yangdipimpinnya, agar orang-orang yangdipimpinnya dapat menerima dan menghargainya sepenuh hati.

3. Motivasi dan dorongan berprestasi

Seorang pemimpin secara relatif mempunyai dorongan motivasi yang kuat untuk berprestasi. Mereka bekerja berusaha mendapatkan penghargaan yang intrinsik dibandingkan dari yang ekstrinsik. Maksudnya adalah seorang pemimpin secara psikologis melakukan usaha/ perbuatan untuk menggerakan, mengarahkan dan meneguhkan tindakan yang berorientasi untuk mencapai tujuan sehingga kondisi ini dapat berarti dan bermanfaat baik bagi diri sendiri maupun pada anggota kelompok/organisasinya yang sifatnya tidak menggharapkan pamrih material atau non material.

4. Sikap-sikap hubungan kemanusiaan

Pemimpin-pemimpin yang berhasil mau mengakui harga diri dan kehormatan para pengikutnya dan mampu berpihak kepadanya. Seorang pemimpin harus mampu mempengaruhi orang-orang yang dipimpinnya agar taat/ patuh, segan/hormat dan mempercayainya sehingga para pengikutnya secara ikhlas dan rela melaksanakan petunjuk, bimbingan, pengarahan,perintah, dan keputusan pimpinannya, baik secara perseorangan maupun dalam bentuk kerjasama. ${ }^{18}$

Sedangkan pendapat Griffin, terdapat 2 konsep kepemimpinan, yaitu : 1) Sebagai proses, kepemimpinan difokuskan kepada apa yang dilakukan oleh para pemimpin, yaitu proses dimana para pemimpin menggunakan pengaruhnya untuk memperjelas tujuan organisasi bagi para pegawai, bawahan, atau yang dipimpinnya, memotivasi mereka untuk mencapai tujuan tersebut, serta membantu menciptakan suatu budaya produktif dalam organisasi. 2) Sebagai atribut, kepemimpinan adalah kumpulan karakteristik yang harus dimiliki oleh seorang pemimpin. Oleh karena itu, pemimpin dapat didefinisikan sebagai seseorang yang memiliki kemampuan untuk mempengaruhi perilaku orang lain tanpa menggunakan kekuatan, sehingga orang-orang yang dipimpinnya menerima dirinya sebagai sosok yang layak memimpin mereka. ${ }^{19}$

18 Miftah Thoha, Perilaku Organisasi (Jakarta: PT. Rajagrafindo Persada, 2008), p. 287-288.

19 Erni Tisnawati Sule dan Kurniawan Saefullah, Pengantar Manajemen (Jakarta: Kencana Prenada Media Group, 2005), p. 255. 
Secara luas dapat dijelaskan bahwa kepemimpinan adalah menyangkut sebuah proses pengaruh sosial yang dalam hal ini pengaruh yang disengaja dijalankan oleh seseorang terhadap orang lain untuk menstrukturkan aktivitas-aktivitas serta hubungan-hubungan di dalam sebuah kelompok atau organisasi.

Selanjutnya menurut Yukl, ada tiga gaya kepemimpinan yang dapat dibedakan antara pemimpin yang efektif dan kepemimpinan yang tidak efektif, yaitu:

a. Perilaku yang berorientasi pada tugas

Para pemimpin yang efektif tidak akan menggunakan waktu dan energinya untuk melakukan pekerjaan yang sama dengan karyawannya. Para pemimpin lebih berkonsentrasi pada fungsi - fungsi yang berorientasi pada tugas misalnya merencanakan, mengelola pekerjaan, mengkoordinasi tugas karyawan, menyediakan peralatan dan bantuan teknis yang dibutuhkan. Pemimpin ini juga memandu karyawannya dalam menetapkan sasaran kinerja yang tinggi.

b. Perilaku yang berorientasi pada hubungan

Para pemimpin lebih perhatian, mendukung, dan membantu para bawahan. Perilaku mendukung ini ditunjukan oleh pemimpin dengan memberikan kepercayaan dan rasa percaya, ramah, berusaha memahami dan memberikan pengakuan atas kontribusi bawahan.

c. Kepemimpinan partisipasif

Kepemimpinan partisipasif berkaitan dengan usaha pemimpin untuk mendorong dan memudahkan partisipasi orang lain dalam pengambilan keputusan. Kepemimpinan ini mencakup konsultasi, pengambilan keputusan bersama, pembagian kekuasaan, desentralisasi dan manajemen yang demokratis. ${ }^{20}$

Berdasarkan berbagai pendapat pengertian kepemimpinan di atas, dapat disimpulkan bahwa masing-masing definisi berbeda menurut sudut pandang penulisnya, namun demikian ada kesamaan dalam mendefinisikan kepemimpinan, yakni pada hakekatnya kepemimpinan adalah kemampuan mempengaruhi perilaku orang lain di mana pemimpin berusaha untuk mengubah tindakan atau sikap dari beberapa kelompok atau subordinates, apakah dia pegawai, bawahan, rekan sekerja,

20 Danang Sunyoto dan Burhanudin, Perilaku Organisasional (Yogyakarta: CAPS, 2011), p. 95. 
atau atasan. Adanya pengikut (followers) yang dapat dipengaruhi baik oleh ajakan, anjuran, bujukan, sugesti, saran atau bentuk lainnya untuk mencapai tujuan yang hendak dicapai. Adapun kepemimpinan mengandung unsur-unsur sebagai berikut: 1) Ada orang/kelompok yang dipengaruhi, 2) Ada tindakan yang diharapkan, 3) Ada tujuan yang ingin dicapai, 4) Ada cara mencapainya yaitu efektif dan efisien.

Selanjutnya untuk mengukur tinggi rendahnya tingkat hasil kepemimpinan efektif, dengan cara membandingkan nilai-nilai aktual dengan standar (normatif) tertentu. H. Malayu S.P. Hasibuan mengatakan bahwa: seorang pemimpin dikatakan sukses atau efektif dalam kepemimpinannya, jika kontuinitas organisasi terjamin dan semua pihak yang terkait memperoleh kepuasan. Dalam hal ini tolak ukurnya menggunakan apakah pemimpin meningkatkan produktivitas organisasi, kepuasan kerja karyawan dan kepuasan pihak terkait. ${ }^{21}$

\section{Pengertian Good Governance}

Secara etimologis governance diartikan sebagai "kepemerintahan sehingga masih banyak orang beranggapan bahwa governance merupakan sinonim dari government". Jika dipahami lebih dalam makna governance dan government memiliki pengertian dan pemahaman yang berbeda, kalau government "mereka" sedangkan governance adalah "kita". 22

Istilah kepemerintahan (governance) berarti tindakan, fakta, dan kegiatan atau penyelenggaraan pemerintahan atau bisa juga diartikan suatu kegiatan (proses) sebagai mana dikemukakan oleh Koiman bahwa governence berarti "serangkain proses interaksi sosial politik antara pemerintahan dengan masyarakat dalam berbagai bidang yang berkaitan dengan kepentingan masyarakat dan interfensi pemerintah atas kepentingan-kepentingan tersebut". Selanjutnya Mardiasmo mengartikan governance sebagai "cara mengelola urusan-urusan publik. Rewansyah mengatakan governance yang merujut pada proses, yaitu "proses penyelenggaraan pemerintahan dalam suatu

${ }^{21}$ Iskandar Putong dan Cecep Hidayat, Teori Kepemimpinan (Jakarta: Mitra Wacana Media, 2010), p. 81.

22 Widodo, dalam (https://dasar-dasar-good-governance-(kepemerintahan-yang-baik).html), 2001, p. 18. diakses tanggal 05 Juni 2019. 
negara dengan melibatkan bukan saja negara, tetepi juga semua stakeholder yang ada baik itu dunia usaha/bisnis dan masyarakat madani (civisociety)". ${ }^{23}$

Pengertian governance diartikan sebagai mekanisme, praktik, dan tata cara pemerintah dan warga mengatur sumber daya serta memecahkan masalah-masalah publik. ${ }^{24}$ Governance sebagai "the way state power is used in managing economic and social resources for development of society" yang artinya cara pemerintah mengelola sumber daya sosial dan ekonomi untuk kepentingan pembangunan masyarakat. ${ }^{25}$

Menurut United Nation Development Program/ UNPD (UNDP) mendefinisikan governance sebagai "the exercise of political, economic, and administrative authority to manage a nation affair at all levels" yang artinya pelaksanaan pada aspek politik, ekonomi, dan administratif dalam pengelolaan negara. ${ }^{26}$ Political governance mengacu pada proses perumusan kebijakan dan implementasi kebijakan yang dilakukan oleh pemegang kekuasaan negara dengan legitimasi rakyat. Dalam pengertian ini, negara harus terdiri dari kekuasaan legislatif, eksekutif dan pengadian yang merepresentasikan pluralitas politik dan memberikan peluang bagi warga negara untuk secara bebas memilih wakil mereka. Economic governance mengacu pada proses pembuatan keputusan dibidang ekonomi yang berimplikasi pada masalah pemerataan, penurunan kemiskinan, dan peningkatan kualitas hidup. Administrative governance mengacu pada sistem implementasi kebijakan yang dilakukan melalui sektor publik dengan karakteristik efisien, independen, akuntabel, dan transparan.

Berdasarkan pengertian governance di atas, dapat disimpulkan bahwa orientasi pembangunan sektor publik menurut Mardiasmo adalah "untuk menciptakan good governance atau pemerintahan yang baik". Arti good dalam good governance mengandung pengertian nilai-nilai yang menjunjung tinggi keinginan rakyat, kemandirian, pembangunan berkelanjutan dan keadilan sosial serta aspek-aspek fungsional dari pemerintahan yang efektif dan efisien. ${ }^{27}$

\footnotetext{
${ }^{23}$ (https://impian-mahasiswa-manfaat-good-governance-bagi-kepentingan-negara-danpemerintahan. html), diakses tanggal 05 Juni 2019.

${ }^{24}$ Hetifah Sj. Sumarto, Inovasi, Partisipasi dan Good Governance,(Jakarta: Yayasan Obor Indonesia, 2003), p. 1.

25 Eddi Wibowo, Memahami Good Government, Governance, dan Good Corporate Governance (Yogyakarta: YPAPI, 2004), p. 9.

26 Ibid., p. 9.

27 Nogi S. Hessel Tangkilisan, Manajemen Publik (Jakarta: PT. Grasindo, 2005), p. 114.
} 
Good governance adalah diaplikasikannya prinsip-prinsip atau nilai-nilai good governance terhadap segala tindakan pemerintah secara luas yang meliputi semua tindakan pemerintah secara luas yang meliputi semua institusi pemerintah dalam semua level pemerintah. ${ }^{28}$ Good governance menurut Bank Dunia ialah: suatu penyelenggaraan manajemen pembangunan yang solid dan bertanggung jawab, sejalan dengan prinsip demokrasi dan pasar yang efisien, penghindaran terhadap kemungkinan salah alokasi dana investasi yang langka, dan pencegahan korupsi secara politik maupun administratif, menjalankan disiplin anggaran serta penciptaan legal andpolitical framework bagi tumbuhnya aktivitas usaha. ${ }^{29}$

Selain itu Bank Dunia juga mensinonimkan good governance sebagai "hubungan sinergis dan konstruktif diantara negara, sektor publik, dan masyarakat". ${ }^{30}$ Menurut Taschereau dan Campos, tata pemerintahan yang baik merupakan "suatu kondisi yang menjamin adanya proses kesejajaran, kesamaan, kohesi, dan keseimbangan peran serta, adanya saling mengontrol yang dilakukan oleh komponen yakni pemerintahan (government), rakyat (citizen) atau civil society dan usahawan (business) yang berada di sektor swasta". 31

Jelaslah bahwa good governance adalah suatu gagasan dan nilai untuk mengatur pola hubungan antara pemerintah, dunia usaha swasta, dan masyarakat sehingga terjadi penyelenggaraan pemerintahan yang bersih, demokratis, dan efektif sesuai dengan cita-cita terbentuknya suatu masyarakat yang makmur, sejahtera, dan mandiri. Menurut United Nation Development Program/ UNDP mendefinisikan: goodgovernance sebagai hubungan yang sinergis dan konstruktif di antara negara, sektor swasta dan masyarakat (society) di mana fungsi-fungsi governance eksis dan bekerja di dalamnya. Pada setiap ranah governance tersebut, terdapat peran-peran yang berbeda dan saling berkesinambungan dalam membentuk sebuah sistem governance. ${ }^{32}$

Berdasarkan pendapat tersebut dapat disimpulkan bahwa good governance pada hakikatnya merupakan hubungan antara institusi negara, pasar dan masyarakat harus

\footnotetext{
28 Eddi Wibowo,Memahami Good Government, p. 54.

${ }^{29}$ Ambar Teguh Sulistiyani, Memahami Good Governance Dalam Perspektif Sumber Daya Manusia (Yogyakarta: Gaya Media, 2004), p. 20.

30 Sofian Effendi, Membangun Budaya Birokrasi Untuk Good Governance. Makalah Seminar Lokakarya Nasional Reformasi Birokrasi (Diselenggarakan Kantor Menteri Negara PAN, 2005), p. 47.

${ }^{31}$ Ambar Teguh Sulistiyani, Memahami Good Governance, p. 21.

32 Eddi Wibowo, Memahami Good Government, p. 19.
} 
sederajat dan saling kontrol, untuk menghindari penguasaan atau eksploitasi oleh satu komponen terhadap komponen lainnya. Dalam penyelenggaraan pemerintahan yang baik, sektor publik atau pemerintah ditempatkan sebagai fasilitator atau katalisator, sementara sektor swasta berperan dalam pembangunan dan masyarakat memonitor akuntabilitas pemerintah itu sendiri. Dengan demikian terjadi hubungan yang sinergis dan kontruktif di antara negara, sektor swasta dan masyarakat. Sektor swasta akan berperan dalam perubahan masyarakat dan akan semakin dominan, sedangkan peran institusi negara semakin mengecil.

Dasar pemikiran makin kecilnya peran negara/pemerintah adalah adanya perubahan manajemen pembangunan dengan peninjauan ulang peran pemerintah dalam pembangunan, yang semula bertindak sebagai regulator dan sekaligus sebagai pelaku pasar menjadi pihak yang mendukung dunia usaha. Akan tetapi dari ketiga domain tersebut, tampaknya domain state menjadi domain yang terpenting dalam mewujudkan good governance. Alasannya adalah Pertama, di dalam domain state melekat fungsi pengaturan, penyediaan layanan, pembangunan, koordinasi dan perencanaan, yang memfasilitasi domain swasta dan masyarakat. Kedua, peran pemerintah melalui kebijakan-kebijakan publiknya sangat penting dalam memfasilitasi terjadinya perubahan-perubahan dalam domain swasta dan masyarakat. Ketiga, dibandingkan domain swasta dan masyarakat maka domain state adalah domain yang dapat diantisipasi perubahannya karena pola penyelengaraannya telah terstruktur.

Oleh sebab itu upaya-upaya ke arah terwujudnya good governance dimulai dengan membangun sistem yang lebih demokratis (demokratisasi) dalam penyelenggaraan negara atau pemerintahan. ${ }^{33}$ Sehingga dapat dikatakan bahwa good governance adalah diaplikasikannya prinsip-prinsip atau nilai-nilai good governance terhadap segala tindakan pemerintah secara luas yang meliputi semua institusi pemerintah dalam semua level pemerintah. ${ }^{34}$

\section{E. Konsep Prinsip-Prinsip Good Governance}

Menurut Bintoro Tjokroamidjojomengatakan prinsip-prinsip good governance antara lain: 1) Akuntabilitas, yaitu tanggung gugat dari pengurusan/penyelenggaraan

\footnotetext{
${ }^{33}$ Ibid., p. 40.

${ }^{34}$ Ibid., p. 54.
} 
dari governance (pengelolaan) yang dilakukan. 2) Transparansi, yaitu dapat diketahuinya oleh banyak pihak (yang berkepentingan) mengenai rumusan kebijaksanaan politik dari Pemerintah, organisasi, badan usaha. 3) Keterbukaan, yaitu pemberian informasi secara terbuka, untuk open free suggestion dan terbuka terhadap kritikyang dilihat sebagai partisipasi untuk perbaikan. 4) Kepastian hukum, legalitas (rule of law) artinya keputusan, kebijaksanaan Pemerintah, organisai, badan usaha yang menyangkut masyarakat. Pihak ketiga dilakukan berdasar hukum (peraturan yang sah). 5) Jaminan, adanya jaminan fairness a level playing field (perlakuan yang adil, perlakuan kesetaraan). Ini berlaku bagi pemerintah kepada masyarakat dalam pelayanan publik, perusahaan kepada pelanggan. ${ }^{35}$

Menurut Gambir Bhatta,good governance antara lain: 1) Accountability (Akuntabilitas), 2) Transparency (Transparansi), 3) Openness (Keterbukaan), 4) Rule of Law (Kepastian Hukum), 5) Management of Competency (Manajemen Kompetensi), 6) Human Right (Hak Asasi Manusia) ${ }^{36}$ Sedangkan menurut Mustopadidjaja, good governance antara lain: 1) Demokrasi dan Pemberdayaan, 2) Pelayanan, 3) Transparansi dan Akuntabilitas, 4) Partisipasi, 5) Kemitraan, 6) Desentralisasi, 7) Konsistensi Kebijakan dan Kepastian Hukum. ${ }^{37}$

Menurut United Nation Development Program (UNDP) dan Bank Dunia tahun 1997 memberikan pendapat mengenai prinsip-prinsip good governance. Kesamaan prinsip-prinsip tersebut, diantaranya adalah "partisipasi, penegakan hukum, transparansi, responsivitas, berorientasi pada konsensus, keadilan, efektivitas dan efisiensi, akuntabilitas, profesionalisme. Namun pelaksanaan good governance dapat diukur dengan empat komponen, yaitu: akuntabilitas, transparansi, keadilan, dan responsivitas". 38

Prinsip-prinsip good governance juga dikemukakan oleh Tim Pengembangan Kebijakan Nasional Tata Kepemerintahan yang Baik, Kementerian Perencanaan Pembangunan Nasional/Bappenas Tahun 2005 (Hasil Revisi) yakni diantaranya adalah: 1. Wawasan ke Depan (Visionary), dengan indikator minimal:

\footnotetext{
35 Sedarmayanti, Good Governance "Kepemerintahan Yang Baik" \& Good Corporate Governance "Tata Kelola Perusahaan Yang Baik". Bagian ketiga. Edisi Revisi (Bandung: CV. Mandar Maju, 2012), p. 15.

36 Ibid., p. 13.

${ }^{37}$ Ibid., p. 14.

38 Eddi Wibowo, Memahami Good Government, p. 55.
} 
- Adanya visi dan strategi yang jelas dan mapan dengan menjaga kepastian hukum.

- Adanya kejelasan setiap tujuan kebijakan.

- Adanya dukungan dari pelaku untuk mewujudkan visi.

2. Keterbukaan dan Transparansi (Openess and Transparancy), dengan indikator minimal:

- Tersedianya informasi yang memadai pada setiap proses penyusunan dan implementasi kebijakan publik.

- Adanya akses pada informasi yang siap, mudah di jangkau, bebas diperoleh dan tepat waktu.

3. Partisipasi Masyarakat (Participation), dengan indikator minimal:

- Adanya pemahaman penyelenggara negara tentang proses/metode partisipatif.

- Adanya pengambilan keputusan yang didasarkan atas konsensus bersama.

4. Tanggung Gugat (Accountability), dengan indikator minimal:

- Adanya kesesuaian antara pelaksanaan dengan standar prosedur pelaksanaan.

- Adanya sanksi yang ditetapkan pada setiap kesalahan atau kelalaian dalam pelaksanaan kegiatan.

5. Supremasi Hukum (Rule of Law), dengan indikator minimal:

- Adanya kepastian dan penegakan hokum

- Adanya penindakan terhadap setiap pelanggar hukum.

- Adanya pemahaman mengenai pentingnya kepatuhan terhadap hukum dan peraturan.

6. Demokrasi (Democracy), dengan indikator minimal:

- Adanya kebebasan dalam menyampaikan aspirasi dan berorganisasi.

- Adanya kesempatan yang sama bagi anggota masyarakat untuk memilih dan membangun konsensus dalam pengambilan keputusan kebijakan public

7. Profesionalisme dan Kompetensi (Profesionalism \& Competency), dengan indikator minimal:

- Berkinerja tinggi.

- Taat asas.

- Kreatif dan inovatif.

- Memiliki kualifikasi di bidangnya. 
8. Daya Tanggap (Responsiveness) , dengan indikator minimal:

- Tersedianya layanan pengaduan dengan prosedur yang mudah dipahami oleh masyarakat.

- Adanya tindak lanjut yang cepat dari laporan dan pengaduan.

9. Keefisienan dan Keefektifan (Efficiency \& Effectiveness), dengan indikator minimal:

- Telaksananya administrasi penyelenggaraan negara yang berkualitas dan tepat sasaran dengan penggunaan sumber daya yang optimal.

- Adanya perbaikan berkelanjutan.

- Berkurangnya tumpang tindih penyelenggaraan fungsi organisasi/unit kerja.

10. Desentarlisasi (Decentralization), dengan indikator minimal:

- Adanya kejelasan pembagian tugas dan wewenang dalam berbagai tingkatan jabatan.

11. Kemitraan dengan Dunia Usaha Swasta dan Masyarakat (Private Sector \& Civil Society Partnership), dengan indikator minimal:

- Adanya pemahaman aparat pemerintah tentang pola-pola kemitraan.

- Adanya lingkungan yang kondusif bagi masyarakat kurang mampu (powerless) untuk berkarya.

- Terbukanya kesempatan bagi masyarakat atau dunia usaha swasta untuk turut berperan dalam penyediaan pelayanan umum.

- Adaya pemberdayaan institusi ekonomi lokal atau usaha mikro, kecil dan menengah serta koperasi.

12. Komitmen pada Pengurangan Kesenjangan (Commitment to reduce Inequality), dengan indikator minimal:

- Adanya langkah-langkah atau kebijakan yang berorientasi pada pemenuhan kebutuhan dasar bagi masyarakat yang kurang mampu.

- Tersedianya layanan-layanan atau fasilitas khusus bagi masyarakat tidak mampu.

- Adanya kesetaraan dan keadilan gender.

- Adanya pemberdayaan kawasan tertinggal.

13. Komitmen pada Lingkungan Hidup (Commitment to Environmental Protection), dengan indikator minimal:

- Adanya keseimbangan antara pemanfaatan sumber daya alam dan perlindungan atau konservasinya. 
- Penegakan prinsip-prinsip pembangunan berkelanjutan.

- Rendahnya tingkat pencemaran dan kerusakan lingkungan.

- Rendahnya tingkat pelanggaran perusakan lingkungan.

14. Komitmen pada Pasar yang Fair (Commitment to Fair Market), dengan indikator minimal:

- Tidak ada monopoli.

- Berkembangnya ekonomi masyarakat.

- Terjaminnya iklim kompetensi yang sehat. ${ }^{39}$

Selanjutnya LAN (Lembaga Administrasi negara) tahun 2003 memberikan prinsipprinsip good governance, antara lain sebagai berikut: 1) Akuntabilitas, 2) Transparansi, 3) Kesetaraan, 4) Supremasi Hukum, 5) Keadilan, 6) Partisipasi, 7) Desentralisasi, 8) Kebersamaan, 9) Profesionalitas, 10) Cepat tanggap, 11) Efektif dan Efisien, 12)Berdaya saing. ${ }^{40}$

Senada dengan pendapat di atas, Undang-Undang Nomor 32 Tahun 2004 yang telah dirubah dengan Undang-Undang Nomor 9Tahun 2015 Tentang Pemerintahan Daerah, pasal 20 tentang Asas Penyelenggaraan Pemerintahan menyatakan bahwa asasgood governance diantaranya adalah: 1) Kepastian hukum, 2) Tertib penyelenggaraan Negara, 3) Kepentingan umum, 4) Keterbukaan, 5) Proporsionalitas, 6) Profesionalitas, 7) Akuntabilitas, 8) Efisiensi, 9) Efektivitas. ${ }^{41}$

\section{F. Tujuan Penerapan Prinsip-Prinsip Good Governance}

Menurut Kementerian Negara Perencanaan Pembangunan Nasional/Badan Perencanaan Pembangunan Nasional gambaran situasi dan kondisi yang terjadi bilamana semua unsur prinsip-prinsip good governance diterapkan antara lain, sebagai berikut:

1. Berkurangnya secara nyata praktik Korupsi, Kolusi, dan Nepotisme (KKN) di birokrasi yang antara ditujukkan adanya beberapa hal berikut: a) Tidak adanya manipulasi pajak, b) Tidak adanya pungutan liar, c) Tidak adanya manipulasi tanah, d) Tidak adanya manipulasi kredit, e) Tidak adanya penggelapan uang Negara, f)

\footnotetext{
${ }^{39}$ Sedarmayanti, Good Governance "Kepemerintahan Yang Baik", p. 22-5.

40 Ibid., p. 20.

41Ibid., p. 21.
} 
Tidak adanya pemalsuan dokumen, g) Tidak adanya pembayaran fiktif, h) Berjalannya proses pelelangan (tender) dengan fair, i) Tidak adanya penggelembungan nilai kontrak (mark-up), j) Tidak adanya uang komisi, k) Tidak adanya penundaan pembayaran kepada rekanan, l) Tidak adanya kelebihan pembayaran, m) Tidak adanya defisit biaya, n) Adanya kepastian hukum.

2. Terciptanya sistem kelembagaan dan ketatalaksanaan pemerintahan yang bersih, efisien, efektif, transparan, professional dan akuntabel, antara lain ditujukkan dengan adanya beberapa hal berikut: a) Lebih efektif, ramping, dan fleksibelnya sistem kelembagaan/ organisasi, b) Lebih baiknya kualitas tata laksana dan hubungan kerja antar lembaga di pusat dan antara pemerintah pusat, provinsi dan kabupaten/ kota, c) Lebih efektif dan efisiennya sistem administrasi pendukung dan kearsipan, d) Dapat dilakukannya upaya penyelamatan, pelestarian, dan pemeliharaan dokumen/ arsip Negara, e) Semakin baiknya hasil kerja organisasi/ institusi dan prestasi pegawai.

3. Terhapusnya peraturan perundang-undangan dan tindakan yang bersifat diskriminatif terhadap warga negara, kelompok, atau golongan masyarakat. Beberapa kondisi yang menunjukkan hal tersebut diantaranya: a) Meningkatnya kualitas pelayanan kepada masyarakat dan dunia usaha swasta, b) Lebih baiknya kualitas sumber daya manusia, prasarana, dan fasilitas pelayanan, c) Berkurangnya hambatan terhadap penyelenggaraan pelayanan public, d) Lebih baku dan jelasnya prosedur dan mekanisme serta biaya yang diperlukan dalam pelayanan public, e) Diterapkannya sistem merit dalam pelayanan, f) Adanya pemanfaatan teknologi informasi dan komunikasi dalam pelayanan public, g) Lebih instensifnya penanganan pengaduan masyarakat.

4. Meningkatnya partisipasi masyarakat dalam pengambilan kebijakan publik yang ditunjukkan dengan berjalannya mekanisme dialog dan musyawarah terbuka dengan masyarakat dalam perumusan program dan kebijakan layanan publik (seperti forum konsultasi publik).

5. Terjaminnya konsistensi dan kepastian hukum seluruh peraturan perundangundangan, baik di tingkat pusat maupun daerah. Dengan demikian, hukum menjadi landasan bertindak bagi aparatur pemerintah dan masyarakat untuk mewujudkan 
pelayanan publik prima. Disamping itu, kalangan dunia usaha swasta akan merasa lebih aman dan terjamin ketika menanamkan modal dan menjalankan usahanya karena ada aturan main (rule of the game) yang tegas, jelas, dan mudah dipahami oleh masyarakat. Aspek positif lainnya adalah tidak akan ada kebingungan di kalangan pemerintah daerah dalam menjalankan tugasnya serta berkurangnya konflik antar pemerintah daerah serta antara pemerintah pusat dengan pemerintah daerah. ${ }^{42}$

\section{G. Penutup}

Berbagai upaya dalam rangka mewujudkan aparatur pemerintah yang berkualitas, bersih dan berwibawa; pemerintah telah menetapkan beberapa peraturan kepegawaian yang harus dilaksanakan oleh semua unsur aparatur pemerintah yang berperan sebagai abdi negara dan abdi masyarakat. Hal ini ditegaskan dalam UndangUndang Nomor 43 Tahun 1999 Tentang Pokok-pokok Kepegawaian dan UndangUndang Nomor 9 Tahun 2015 dikatakan bahwa efektivitas dan efesiensi penyelenggaraan pemerintahan daerah perlu untuk ditingkatkan dengan lebih memperhatikan aspek-aspek hubungan antar susunan pemerintahan dan antar pemerintahan daerah, potensi dan keanekaragaman daerah, peluang dan tantangan persaingan global dengan memberikan kewenangan yang seluas-luasnya kepada daerah disertai dengan pemberian hak dan kewajiban penyelenggaraan otonomi daerah.

Sekarang ini kinerja instansi pemerintah menjadi sorotan dari berbagai pihak, terutama sejak berkembangnya gerakan reformasi yang menuntut perubahan struktural di berbagai bidang. Perubahan yang paling mendasar adalah untuk mewujudkan karakter pemerintahan yang demokratis, transparan, akuntabel, bersih dan bebas korupsi, berorientasi kepada pasar dan peran serta aktif masyarakat dalam berbagai bidang. Singkatnya dewasa ini sedang terjadi perubahan dari pola kepemerintahan yang buruk (bad governance) kearah terwujudnya kepemerintahan yang baik (good governance).

Salah satu upaya untuk mencapai tingkat efisiensi kerja organisasi diperlukan adanya peningkatan kinerja pegawai. Tujuannya adalah dalam konteks meningkatkan kualitas, efektivitas dan efesiensi kinerja pegawai termasuk kemampuan, disiplin,

42 Kementerian Negara Perencanaan Pembangunan Nasional, Penerapan Tata Kepemerintahan Yang Baik (Jakarta: Badan Perencanaan Pembangunan Nasional/ Bappenas, 2007). 
pengabdian, keteladanan dan kesejahteraan aparatnya serta untuk meningkatkan kemampuan dalam melayani, mengayomi serta menumbuhkan prakarsa dan peran aktif masyarakat dalam pembangunan dan tanggap terhadap kepentingan aspirasi masyarakat. Dengan kepemimpinan yang baik, maka akan dapat menerapkan prinsipprinsip good governance di semua organisasi atau instansi.

Untuk mewujudkan konsep kepemimpinan atau leadership adalah merupakan sebuah upaya yang sulit karena akan timbul sudut pandang yang berbeda, tetapi paling tidak ada beberapa hal tentang kepemimpinan tersebut. Ada empat sifat umum yang mempengaruhi pengaruh terhadap keberhasilan kepemimpinan organisasi, yaitu: 1) Kecerdasan. 2) Kedewasaan dan keluasan hubungan sosial. 3) Motivasi dan dorongan berprestasi. 4) Sikap-sikap hubungan kemanusiaan. 5) Berorientasi tugas dan kewenangan. 6) Jujur dan terbuka. 7) Demokrastis dan administratif. 8) Berpartisipasi dan bertanggungjawab.

Sedangkan untuk prinsip-prinsip good governance paling tidak ada beberapa hal yang harus ditegakkan dan dilakukan, yaitu: 1) Akuntabilitas.2) Transparansi. 3) Keterbukaan. 4) Kepastian hukum-legalitas (rule of law). 5) Jaminan. 6) Partisipasi (kemitraan). 7) Desentralisasi. 8) Profesional dan proporsional. 9) Efektif dan efisien. 10) Produktivitas dan kualitas kerja. 


\section{Daftar Pustaka}

Cahyani, Ati, 2003, Dasar-Dasar Organisasi dan Manajemen. Jakarta: Grasindo.

Effendi, Sofian, 2005, Membangun Budaya Birokrasi Untuk Good Governance. Makalah Seminar Lokakarya Nasional Reformasi Birokrasi. Diselenggarakan Kantor Menteri Negara PAN.

https://impian-mahasiswa-manfaat-good-governance-bagi-kepentingan-negara dan pemerintahan.html, diakses tanggal 05 Juni 2019.

Kaloh. J., 2009, Kepemimpinan Kepala Daerah: Pola Kegiatan, Kekuasaan, dan Perilaku Kepala Daerah dalam Pelaksanaan Otonomi Daerah. Jakarta: Sinar Grafika.

Kartono, Kartini, 2006, Pemimpin dan Kepemimpinan. Jakarta. Raja Grafindo Persada.

Kementerian Negara Perencanaan Pembangunan Nasional, 2007, Penerapan Tata Kepemerintahan Yang Baik. Jakarta: Badan Perencanaan Pembangunan Nasional (Bappenas).

Matondang, 2008, Kepemimpinan Budaya Organisasi dan Manajemen Stratejik. Yogyakarta: Graha Ilmu.

Nasution, M.N., 2001, Manajemen Mutu Terpadu. Jakarta: Ghalia Indonesia.

Nawawi, Hadari, 2006, Kepemimpinan Mengefektifkan Organisasi. Yogyakarta: BPFE.

Pasolong, Harbani, 2010, Teori Administrasi Publik. Bandung: CV. Alfabeta.

Putong, Iskandar dan Hidayat, Cecep, 2010, Teori Kepemimpinan. Jakarta: Mitra Wacana Media.

Sedarmayanti, 2012, Good Governance "Kepemerintahan Yang Baik" \& Good Corporate Governance "Tata Kelola Perusahaan Yang Baik". Bagian ketiga. Edisi Revisi. Bandung: CV. Mandar Maju.

Siagian, Sondang P., 2012, Kiat Meningkatkan Produktivitas Kerja, Jakarta: PT. Renika Cipta.

Sule, Erni Trisnawati dan Saefullah, Kurniawan, 2005, Pengantar Manajemen, Jakarta: Kencana Prenada Media Group.

Sulistiyani, Ambar Teguh. Memahami Good Governance Dalam Perspektif Sumber Daya Manusia. Yogyakarta: Gaya Media, 2004.

Sumarto, Hetifah Sj., 2003, Inovasi, Partisipasi dan Good Governance, Jakarta: Yayasan Obor Indonesia.

Sunyoto, Danang dan Burhanudin, 2011, Perilaku Organisasional, Yogyakarta: CAPS.

Syafi'ie, Inu Kencana, 2003, Kepemimpinan Kepemerintahan Indonesia. Bandung: PT. Refika Aditama.

Tangkilisan, Nogi S. Hessel, 2005, Manajemen Publik, Jakarta: PT. Grasindo.

Thoha, Miftah, 2008, Perilaku Organisasi, Jakarta: PT. Rajagrafindo Persada.

Undang-Undang Nomor 43 tahun 1999 Tentang Pokok-pokok Kepegawaian.

Undang-Undang Nomor 9 Tahun 2015 Perubahan Kedua Atas Undang-undang Nomor 32 Tahun 2004 Tentang Pemerintahan Daerah.

Usman, Husaini, 2009, Manajamen, Jakarta: Bumi Akshara. 
Wibowo, Eddi, 2004, Memahami Good Government, Governance, dan Good Corporate Governance, Yogyakarta: YPAPI.

Widjaja, A.W., 2003, Pola Kepemimpinan dan Kepemimpinan Pancasila, Bandung: Armico.

Widodo dalam (https://dasar-dasar-good-governance (kepemerintahan-yang-baik). html, diakses tanggal 05 Juni 2019. 